\title{
SIASAT . Hal: $1-12$ \\ STIMULATION INTELLECTUAL AND INDIVIDUALIZED CONSIDERATION IN LEADING EMPLOYEES: A STUDY IN ONE LOCAL AUTHORITY
}

\author{
Azman Ismail and Shairazi Samsudin \\ Faculty of Cognitive Sciences and Human Development \\ Universiti Malaysia Sarawak. \\ Email: iazman@fcs.unimas.my
}

Asmai Ishak

Fakulty of Economics

Universitas Islam Indonesia

\begin{abstract}
This study was conducted to measure the effect of transformation leadership characteristics (i.e., intellectual stimulation and individualized consideration) and empowerment on service quality using 110 usable questionnaires gathered from employees who have worked in one city based local authority in Sarawak, Malaysia (AUTHORKEM). Stepwise regression analysis showed that the inclusion of empowerment in the analysis had increased the effect of transformational leadership characteristics on service quality. The result confirms that empowerment does act as a full mediating role in leadership model of the studied organization.
\end{abstract}

Key words: transformational leadership, empowerment, service quality

\section{INTRODUCTION}

In the early studies of human resource development, the characteristics of leadership styles were given much emphasized (Spreitzer, 1995; Yammariono Dubinsky, 1994). For example, transactional leadership and transformational leadership are two important organizational leadership styles that have received much attention many years ago (Bass, 1988; 1990; Bass \& Avolio, 1993; Hartog, et al., 1997). Transactional leadership emphasizes on cost benefit where the exchange of commodities (e.g., rewards) is used as a main instrument to achieve organizational and job goals (Howell \& Avolio, 1993; Pounder, 2002). For example, in this exchange process a leader often promises to fulfil followers' needs (e.g. wages, promotion) if they complies the his/her wishes (Bass, 1990, 1994; Jabnoun \& AL-Rasasi, 2005). In an era of global competition, many organizations shift the paradigms of their management styles from a transactional leadership based to transformational leadership in order to achieve their strategies and goals (Bass, 1990, 1994; Howell \& Avolio, 1993; Humphrey, 2002). According to organizational leadership scholars, such as Bass (1994), Bass and Avolio (1994), and Hartog et al. (1997) define transformational leadership as leaders who want to develop their followers' full potentials, higher needs, good value systems, moralities and motivation. When this development occurs this may motivate followers to unite, change goals and beliefs (Bass, 1990, 1994; Bycio et al., 1995), and look forward beyond their self interests (Hartog et al., 1997; Keller, 1995).

Extant research in this area shows that the ability of leaders to properly use transformational styles may affect service 
quality (Humphreys, 2002, Pounder, 2002). For example, intellectual stimulation and individualized consideration are most salient transformational leadership characteristics that strongly affect service quality (Bass \& Avolio, 1994; Avolio et al., 1999; Jabnoun \& AL Rasasi, 2005). According to several scholars, such as Dionne et al. (2003), intellectual stimulation is often viewed as a leader cares about intelligence, rationality, logic and careful problem solving in organizations. Leaders implement this approach through stimulating followers to re-examine traditional ways of doing things, and encourage them to try novel and creative approaches (e.g., interesting and challenging tasks) (Bass \& Avolio, 1994; Yammarino \& Dubinsky, 1994). Besides that, individualized consideration is viewed as a leader who cares about their followers' concerns and developmental needs. This idea encourages leaders to develop followers' potentials through proper coaching and mentoring, continuous feedback and link followers' needs to organizational strategy and goals (Bass \& Avolio, 1994; Avolio et al., 2004).

Many quality management scholars, such as Parasuraman, Zeithmal and Berry (1985, 1988), Jabnoun and Al Rasasi (2005) and Jun et al. (1988) define service quality as a multidimensional concept where it often emphasizes on the delivery of products that meet five generic quality features: reliability, responsiveness, tangibles, assurance and empathy. Reliability is often associated with the willingness of a service provider to perform the service dependably and accurately. Responsiveness is usually seen as the willingness of a service provider to be helpful and punctual in providing services. Tangible is referred as the physical appearance of service facilities, equipments, staff and communication materials. Assurance is viewed as a service provider's knowledge, courtesy and ability in conveying trust and confidence. Empathy is often related to the readiness of a service provider to increase the level of caring and individual attention when dealing with customers. Within a transformational leadership framework, the ability of leaders to properly stimulate followers' intellectuals and develop their potentials in performing duties and responsibilities (Bass, 1994; Bass \& Avolio, 1994; Avolio et al., 2004) may directly increase the quality of service deliveries, such as satisfy and retain customers (Humpreys, 2002; Spreng et al., 1996), eliminate the source of the complaints and continue relationship with customers (Jabnoun \& AL Rasasi, 2005; Pounder, 2002).

Surprisingly, a careful observation about such relationships reveals that effect of intellectual stimulation and individualized consideration on service quality is indirectly affected by empowerment (Bartram \& Casimir, 2007; Klidas et al., 2007). Empowerment is viewed as proactive and strategic management practice that exists in an organization that promotes high commitment HR practices (Menon, 2001; Spreitzer, 1995), which reveals that leaders willingness to delegate the power and responsibility of controlling, making and sharing decisions to their followers in managing organizational functions (Bowen \& Lawler, 1992; Honold, 1997; Sternberg, 1992; Lashley, 1999). In a transformational leadership context, for example, leaders who give sufficient power to followers in planning and implementing job will motivate their intellectuals and potentials to improve service quality in organizations The nature of this relationship is interesting, but little is known about the mediating role of empowerment in transformational leadership models (Bartram \& Casimir, 2007; Klidas et al., 2007). Hence, it motivates the researchers to examine the mediating role of empowerment in the relationship between selected transformational leadership characteristics (i.e., intellectual stimulation and 
individualized consideration) and service quality that occurs in one city based local authority (AUTHORKEM) in Sarawak, Malaysia.

\section{LITERATURE REVIEW Context of the Study}

AUTHORKEM is a state owned agency that has been established to realize the organization's vision, that is attractive, cultured, clean and safe city. In order to support this vision, the management has set up the organization mission that emphasizes on the improving delivery of services to enhance the quality of life for its community. The researchers conducted the in-depth interviews involving four experienced employees to understand the role of leadership in achieving the organization's mission and vision. The information gathered from the interview reveals that staff of the organization can be divided into two major categories: management employees and supporting employees. Management employees are leaders (i.e., department heads, assistant department heads and supervisors) that are given duties and responsibilities to plan, organize, lead and monitor employee jobs in the organization. Supporting employees are followers (e.g., general administration assistants, personal assistants to department heads and technicians) that are hired to assist their bosses in achieving the organizational and job targets. At a departmental level, management employees often use policies and procedures set up by the stakeholders (i.e., senior management team, board of directors, chief minister office and/or central government agency) as guidelines to ensure integrity and accountability in implementing management functions, such as general service, human resource, finance, and technical activities.

These guidelines provide insufficient power to management employees in designing broad policies and procedures, but they are given more opportunity to stimulate followers' intellectuals and develop their potentials in achieving organizational and job targets. For example, management employees promote intellectual stimulation through encouraging followers to think and try new ways in completing tasks (e.g., human resource information system, internet, automations and machineries), ask follower opinions in making decisions (e.g., enforcing rules and regulations), and motivate followers to use their capabilities in doing challenging works (e.g., applying knowledge, skills and attitudes gained from training programs). Besides that, management employees emphasize individualized consideration through conducting one-toone conversation about the work progress (e.g., teamwork), assist followers to complete works when needed (e.g., physical facilities and work schedules), and appreciate the strengths and weaknesses of each follower (e.g., skill based courses). If management employees can properly implement such transformational styles this will increase followers' empowerments in planning and performing job. Consequently, it may lead to an increased service quality (e.g., followers care 24-hours tele-service to receive reports from customers, courtesy when dealing with the customers, take action for minor complaints received within 24 hours, and perform action for major complaints received within three days). Even though the nature of such relationships is interesting, however it is little known about the mediating role of empowerment in the leadership model of the studied organization (Samsudin, 2008).

Relationship between Intellectual Stimulation, Individualized Consideration, Empowerment and Service Quality

The mediating role of empowerment in leadership management model of the AUTHORKEM gains strong support from 
transformational leadership studies conducted in Western and Eastern organizational settings. For example, Jabnoun and AL Rasasi (2005) conducted a study on transformational leadership in six UAE hospitals. This study found that intellectual stimulation and individualized consideration had increased service quality in the organizations. Besides that, Bartram \& Casimir (2007) examined the transformational leadership constructs based on a sample of 150 customer service operators in an Australian call-centre. The study found that the ability of leaders to properly implement intellectual stimulation and individualized consideration has increased employees' empowerments in performing job. As a result, it could lead to higher service quality. Further, Klidas et al. (2007) surveyed the empowerment role using 356 frontline employees of 16 luxury hotels in European countries. The study found that properly implemented intellectual stimulation and individualized consideration had increased the followers' empowerments in delivering services. As a result, it could lead to higher service quality in the organization.

The leadership research literature is consistent with the notion of leadership theories, namely Burns' (1978) transformational leadership theory, and Bass's (1985) transformational leadership theory. Specifically,
Burns' (1978) transformational leadership theory highlights that mutual understanding of leaders and followers in managing organizational functions may increase their moralities. Besides that, Bass's (1985) transformational leadership theory posits that interaction between leaders and followers in managing organizational functions can inspire followers to go beyond their selfinterests for supporting the organization interests. Application of these theories in an organizational leadership framework shows that followers' moralities and concern about organizational interests can be developed if leaders stimulate followers intellectuals and develop their potentials in managing organizational functions (Bass, 1990, 1994; Bycio et al., 1995; Dionne et al., 2003; Hartog et al., 1997). When such leadership styles are properly implemented this will increase followers' empowerments to perform job better because they believe that they can use their creativities and innovations to achieve difficult goals (Lashley, 1999; Locke \& Latham, 1991; Pounder, 2002; Waldman, 1993). As a result, it may lead to an improved service quality in organizations (Bartram \& Casimir, 2007; Klidas et al., 2007).

The literature has been used as foundation to develop a conceptual framework for this study as shown in Figure 1.

\section{Independent variable Mediating variable Dependent variable}

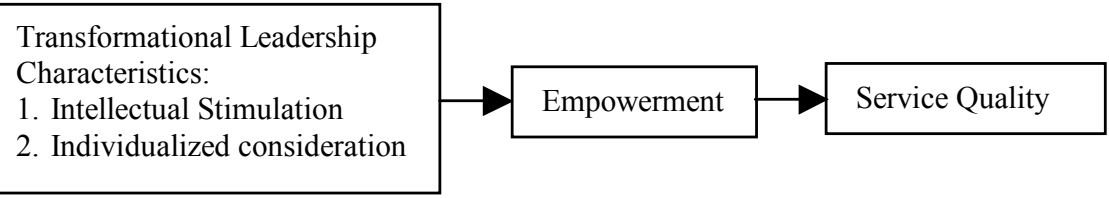

Figure 1: Empowerment Mediates the Effect of Transformational Leadership Characteristics on Service Quality 
Based on the framework, it seems reasonable to assume that high empowerments in performing job will influence AUTHORKEM employees as this practice influences Western and Eastern employees. Transformational leadership theories suggest that if AUTHORKEM employees have high opportunities to use empowerments in performing jobs, this may lead to higher service quality. Therefore, it was hypothesized that:

H1: Empowerment mediates the effect of intellectual stimulation on service quality.

$\mathrm{H} 2$ : Empowerment mediates the effect of individualized consideration on service quality.

\section{METHODOLOGY}

This study used a cross-sectional research design that allowed the researchers to integrate training management literature, the in-depth interview, the pilot study and the actual survey as a main procedure to gather data. The use of such methods may gather accurate and less biased data (Cresswell, 1998; Sekaran, 2000). This study was conducted at one city based local authority (AUTHORKEM) in Sarawak, Malaysia. At the initial stage of this study, in-depth interviews were conducted involving four experienced employees, namely HR manager, Head of Training Unit and two experienced supporting staffs in the Human Resource Department of the organization. Information gathered from the interviews was used to develop the content of a pilot survey questionnaire. Next, a pilot study was done by discussing the survey questionnaires with the participants in order to understand leadership styles, empowerment characteristics, service quality characteristics and the relationship of such variables in the studied organization. This information was used to verify the content and format of survey questionnaires for an actual study.
The survey questionnaire has 4 sections. Firstly, intellectual stimulation had 10 items and individualized consideration had 10 items that were modified from the multi factor leadership questionnaires (Avolio et al., 1999; Bass, 1990, 1994; Bycio et al., 1995; Dionne et al., 2003; Hartog et al., 1997). The items used to measure intellectual stimulation were: (1) provides me with assistance in exchange for my efforts, (2) reexamines critical assumptions to questions whether they are appropriate, (3) encourage me to seek different perspective when solving problems, (4) goes beyond self-interest for the good of the group, (5) considers the moral and ethical consequences of decisions I make regarding my work, (6) gets me to look at problems from many different angles, (7) suggest new ways of looking at how to complete an assignment, (8) encourage me to do more than I expected to do, (9) effective in representing me to higher authority, and (10) increase my willingness to try harder. The items used to measure individualized consideration were: (1) talk optimistically about the future, (2) instill pride in me for being associated with him/her, (3) talks enthusiastically about what needs to be accomplished, (4) specifies the importance of having strong sense of purpose, (5) spends time teaching and coaching, (6) treats me as individual rather than just as a member of a group, (7) articullate compelling vission of the future, (8) considers me as having different needs, abilities, and aspirations from others, (9) helps me to develop my strength, and (10) heightens my desire to succed.

Secondly, empowerment was measured using 7 items that were modified from the service management literature (Klidas et al., 2007). The items used to measure this variable were: (1) confident in my ability to do my work, (2) the work that I do is important to me, (3) come up with creative ways to please customers, (4) the 
support and authority to make the decisions necessary for accomplishing assigned task, (5) take initiatives beyond what is expected of me in order to please the customer, (6) rely on my own judgement to make most of the decisions required in my job, and (7) enough involvement in decisions that affect my work.

Finally, the service quality was measured using 12 items that were modified from the SERVQUAL questionnaire (Parasuraman et al., 1985, 1988). The items used to measure this variable were: (1) provide services based on the organization's policies, (2) show a sincere interest in helping customers when they are having a problem, (3) deliver my service correctly at any time, (4) inform the customers when services will be performed, (5) give prompt services to the customers, (6) never be too busy to respond to customers' request, (7) the appropriate knowledge to answer customers' questions, (8) be consistently courteous to the customers, (9) instill confidence in the customers when providing services, (10) give personal attention to the customers when I provide services, (11) understand the needs of the customers, and (12) the customers' best interest at heart. All items used in the questionnaires were measured using a 7-item scale ranging from "strongly disagree" (1) to "strongly agree" (7). Demographic variables were used as a controlling variable because this study also focused on employees' attitudes. The back translation technique was used to translate the survey questionnaires in Malay and English; this may help to increase the validity and reliability of the instrument (Van Maanen, 1983; Wright, 1996).

The targeted population of this study was employees of the AUTHORKEM. This organization has 1007 officers employed, 35 professionals' full time staff, 696 support staff and 276 daily paid workers. In a data collection, HR manager did not provide the list of registered employees according to departments and did not allow the researchers to distribute survey questionnaires to every department who work in the studied organization. Considering the constraints of organizational rule, a convenience sampling technique was used to distribute 260 survey questionnaires to employees via contact persons (i.e., HR manager, assistant HR managers and supervisors) in the organization. Of the number, 110 usable questionnaires were only returned to the researchers, yielding a response rate of 42.31 percent. The survey questionnaires were answered by participants based on their consent and voluntary basis. The number of survey participants exceeds the minimum sample of 30 respondents as required by probability sampling technique. Thus, the data collected can be analyzed using inferential statistics (Leedy \& Ormrod, 2005; Sekaran, 2000).

\section{RESULTS}

Table 1 shows the sample profile of this study. The majority of respondents were females (56.4 percent) than males (43.6 percent), respondents' ages more than 40 years old (30.9 percent), Malay (67.3 percent), Malaysia Certificate of Education (55.5 percent), and worked more than 10 years (58.2 percent).

Table 2 shows the results of validity and reliability analyses for measurement scales. The factor analysis with direct oblimin rotation was done for four variables with 37 items, which relates to four variables which are intellectual stimulation (10 items), individualized consideration (10 items), empowerment ( 7 items), and quality service (10 items). Next, the Kaiser-MayerOlkin Test (KMO), which is a measure of sampling adequacy, was conducted for each variable and the results indicated that it was acceptable. Specifically, the results of these statistical analyses showed that (1) all 
research variables exceeded the minimum standard of Kaiser-Meyer-Olkin's value of 0.6, were significant in Bartlett's test of sphericity, (2) all research variables had eigenvalues larger than 1, (3) the items for each research variable exceeded factor loadings of 0.40 (Hair et al., 1998), and (4) all research variables exceeded the acceptable standard of reliability analysis of 0.70 (Nunally \& Bernstein, 1994). These statistical results confirmed the validity and reliability of measurement scales used for this study as shown in Table 2.

Table 3 shows the results of Pearson correlation analysis and descriptive statistics. The means for the variables are from 5.24 to 5.91 , signifying that the level of intellectual stimulation, individualized consideration, empowerment and service quality are ranging from high (5.24) to highest (5.91). The correlation coefficients for the relationship between the independent variable (i.e., intellectual stimulation and individualized consideration) and the mediating variable (i.e., empowerment), and the relationship between the dependent variable (i.e. service quality) were less than 0.90 , indicates that the data were not affected by serious collinearity problem (Hair et al., 1998). The measurement scales that had met the validity and reliability standards thus were used to test research hypotheses.

Table 1: Participants' Characteristics

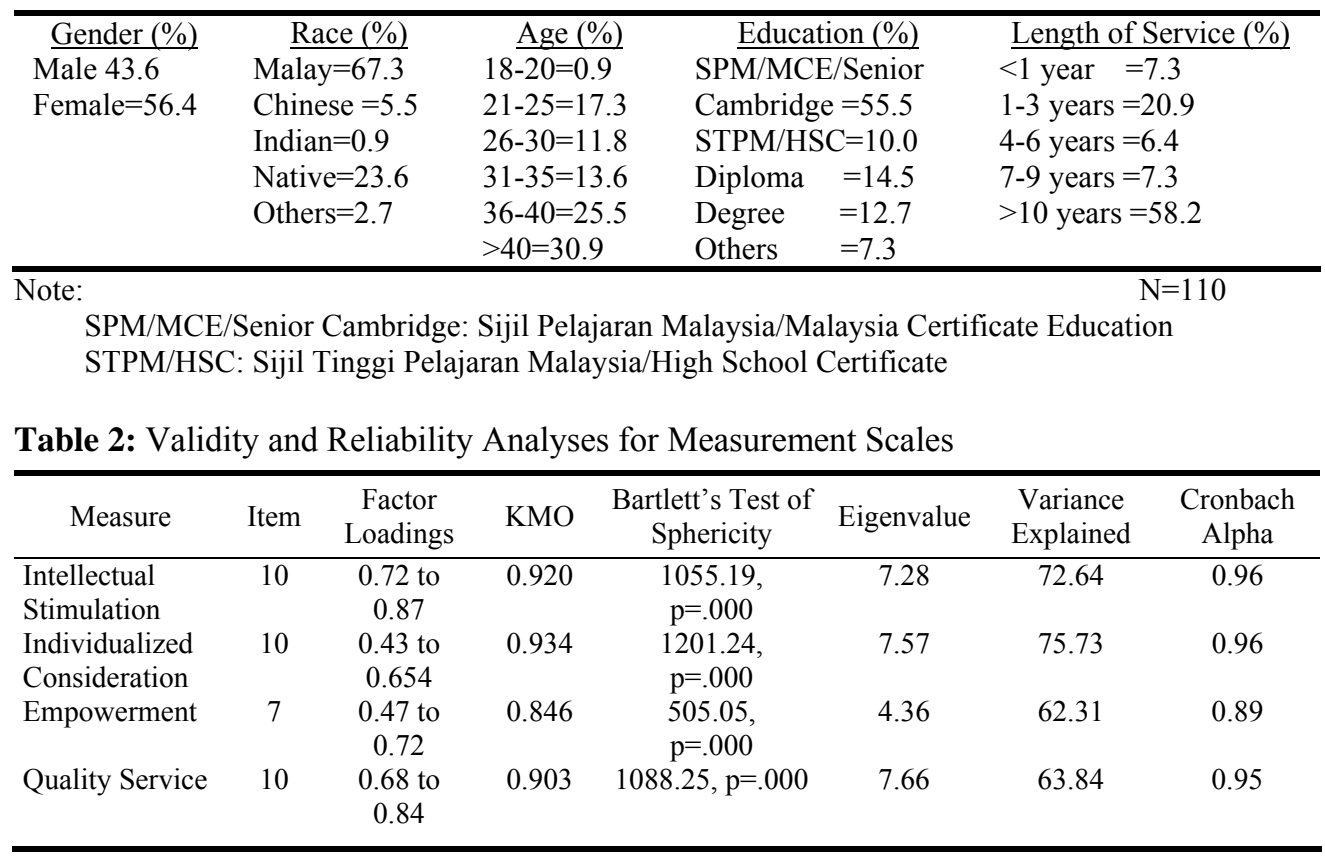


Table 3: Pearson Correlation Analysis and Descriptive Statistics

\begin{tabular}{lcclclll}
\hline \multirow{2}{*}{ Variables } & \multirow{2}{*}{ Min } & $\begin{array}{c}\text { Standard } \\
\text { Deviation }\end{array}$ & \multicolumn{4}{c}{ Pearson Correlation (r) } \\
\cline { 7 - 8 } & & & 1 & 2 & 3 & 4 \\
\hline 1.Intellectual Stimulation & 5.29 & 1.12 & & $(1)$ & & & \\
2.Individualized Consideration & 5.24 & 1.11 & $0.79^{* *}$ & $(1)$ & & \\
3. Empowerment & 5.66 & 0.73 & $0.42^{* *}$ & $0.53^{* *}$ & $(1)$ & \\
4. Service Quality & 5.91 & 0.81 & $0.39^{* *}$ & $0.48^{* *}$ & $0.73^{* *}$ & $(1)$
\end{tabular}

Note: Correlation Value is significant at $* \mathrm{p}<0.05, * * \mathrm{p}<0.01, * * * \mathrm{p}<0.001$

Reliability estimation are shown diagonally (value 1 )

Pearson correlation analysis was unable to determine the mediating role of motivation to learn in the hypothesized model. Stepwise regression analysis was undertaken to test the mediating hypothesis because it can assess the magnitude of each independent variable, and vary the mediating variable in the relationship between many independent variables and one dependent variable (Baron \& Kenny, 1986; Foster et al., 1998). According to Baron and Kenny (1986), the mediating variable can be considered when it meets three conditions: first, the predictor variables are significantly correlated with the hypothesized mediator. Second, the predictor and mediator variables are all significantly correlated with the dependent variable. Third, a previously significant effect of predictor variables is reduced to non-significance or reduced in terms of effect size after the inclusion of mediator variables into the analysis (Wong et al., 1995). In this regression analysis, standardized coefficients (standardized beta) were used for all analyses (Jaccard et al., 1990). Moreover, the results of testing hypotheses can be seen in Table 4 .

Table 4: Outcomes of Stepwise Regression Analysis

\begin{tabular}{lccc}
\hline \multirow{2}{*}{ Variables } & \multicolumn{3}{c}{ Dependent Variable } \\
\cline { 2 - 4 } & Step 1 & Step 2 & Step3 \\
\hline Control Variables & & & \\
Gender & 0.01 & -0.04 & 0.03 \\
Age & -0.10 & -0.17 & -0.12 \\
Race & -0.23 & -0.21 & -0.12 \\
Education Level & 0.18 & 0.10 & 0.08 \\
Length of Service & 0.18 & 0.30 & 0.20 \\
\hline Independent Variables & & & 0.04 \\
Intellectual Stimulation & & 0.02 & 0.11 \\
Individualized Consideration & & $0.48^{* *}$ & \\
Mediating Variable & & & $0.63^{* * *}$ \\
\hline Empowerment & 0.27 & 0.55 & 0.75 \\
\hline$R$ Square & 0.03 & 0.25 & 0.53 \\
Adjust R Square & 0.07 & 0.22 & $16.50^{* * *}$ \\
R square change & 1.65 & $6.16^{* * *}$ & $62.76^{* * *}$ \\
F & 1.65 & $16.22^{* * *}$ &
\end{tabular}

Note: Significant at $* * \mathrm{p}<0.01 ; * * * \mathrm{p}<0.001$ 
This table shows the inclusion of empowerment in Step 3 of the process reveals that relationship between empowerment and selected transformational leadership characteristic (i.e., intellectual stimulation and individualized consideration) significantly correlated with service quality $(\beta=.63, \mathrm{p}=0.000)$, therefore $\mathrm{H} 1$ and $\mathrm{H} 2$ were fully supported. This relationship explains that before the inclusion of empowerment into the analysis in Step 2, intellectual stimulation was found to be not significantly correlated with service quality $(\beta=.02$, $\mathrm{p}=0.892$ ), while individualized consideration was found to be significantly correlated with service quality $(\beta=.48, p=0.001)$. As shown in Step 3 (after the inclusion of empowerment into the analysis), the previous insignificant relationship between intellectual stimulation and service quality did not change to significant (Step 3: $\beta=.04, p=0.72$ ) while the previous significant relationship between individualized consideration and service quality became non-significant (Step 3 : $\beta=.11, p=.34)$. In terms of explanatory power, the inclusion of empowerment in Step 3 had explained 75 percent of the variance in dependent variable. This result confirms that the inclusion of empowerment into the analysis has increased the strength of relationship between selected transformational leadership characteristics (i.e. intellectual stimulation and individualized consideration) and service quality, which sends a signal that empowerment does act as a full mediating variable in the organization.

\section{DISCUSSION AND IMPLICATION}

This study confirms that effect of intellectual stimulation and individualized consideration on service quality is indirectly affected by empowerment in the studied organization. In the AUTHORKEM, leaders have actively stimulated followers' intellectuals and potentials in implementing management functions. The majority employees perceive that such leadership styles had increased their empowerments in planning and implementing job. When employees perceive that their empowerments are high, this may motivate them to increase service quality in the organization.

The implications of this study can be divided into three major aspects: theoretical contribution, robustness of research methodology, and contribution to practitioners. In term of theoretical contribution, this study revealed that empowerment does act as a mediating variable in the relationship between selected leadership features (i.e., intellectual stimulation and individualized consideration) and service quality. This outcome is consistent with studies by Batram and Casimir (2007), and Klidas et al. (2007). In sum, the findings of this study have supported and broadened leadership research literature mostly published in Western and Eastern organizational settings. Thus, the notion of empowerment has been successfully applied within the leadership management models of the studied organization. With respect to the robustness of research methodology, the data gathered using leadership management literature, the in-depth interviews, pilot study and survey questionnaires have exceeded an acceptable standard of validity and reliability analysis, this may lead to the production of accurate and reliable findings.

Regarding practical contributions, the findings of this study can be used as a guideline by the management to upgrade the effectiveness of leadership styles in their organizations. This objective may be achieved if the management consider these suggestions: firstly, leadership styles will be sharpened if they are continuously trained with up to date knowledge, relevant skills and good moral values. This training program can help to improve leaders' treatments in handling the needs and demands of employees who have different socio-econ- 
omy backgrounds. Secondly, participative leadership styles can be meaningful if followers are allowed to involve in decision making, this motivate employees to perceive that their contributions are appreciated, this may motivate them to use their own creativity and innovations in performing job. Finally, interaction between followers and leaders will increase positive subsequent personal outcomes (e.g., satisfaction, commitment, performance and ethics) if organizations provide merit based pay (e.g., monetary incentives) to high performing employees. This pay system may motivate followers and leaders to give more focus and consistency in achieving job targets. If employers heavily consider these suggestions, this may positively motivate followers and leaders to support organisational strategies and goals.

\section{CONCLUSION}

This study confirms that empowerment does act as a full mediating role in the relationship between intellectual stimulation, individualized consideration and service quality. This result has supported and extended leadership research literature mostly published in Western and Eastern organizational settings. Therefore, current research and practices within transformational leadership models needs to consider empowerment as a crucial aspect of organisational leadership styles where increasing followers' empowerments in planning and implementing job may strongly induce positive subsequent personal outcomes (e.g., competency, performance, satisfaction, commitment, trust, and positive moral values). Hence, these positive outcomes may motivate employees to sustain and support organisational strategy and goals.

\section{REFERENCES}

Avolio B.J., Zhu W., Koh W. \& Bhatia P., (2004), "Transformational leader- ship and organizational commitment: Mediating role of psychological empowerment and moderating role of structural distance". Journal of Organizational Behaviour, 25: 951-968.

Avolio, B.J., Bass, B.M., \& Jung, D.I., (1999), "Re-examining the components of transformational and transactional leadership using the multifactor leadership questionnaire". Journal of Occupational and Organizational Psychology, 72 (4), 441-462.

Baron, R.M \& Kenny, D.A., (1986), "This moderator-mediator variable distinction in social psychological research: conceptual, strategic, and statistical considerations". Journal of Personality and Social Psychology, 51 (6): 1173-1182.

Bartram, T. \& Casimir, G., (2007), "The relationship between leadership and follower in-role performance and satisfaction with the leaders: The mediating effects of empowerment and trust in the leader". Leadership \& Organization Development Journal, 28 (1): 4-19.

Bass, B.M., (1985), Leadership and performance beyond expectations. Free Press New York. NY.

Bass, B.M., (1988), "The inspirational process of leadership". Journal of Management Development, 7: 21-31.

Bass, B.M., (1990), Bass and Stogdill's handbook of leadership: theory research and managerial applications. 3rd ed. Free Press New York. NY.

Bass, B.M., (1994), Transformational leadership and team and organiza- 
tional decision making. Sage Thousand Oaks. CA.

Bass, B.M., \& Avolio, B., (1993), "Transformational leadership and organizational culture". Public Administration Quarterly, 17, 112-21.

Bass, B.M., \& Avolio, B., (1994), Improving organizational effectiveness through transformational leadership. Sage Thousand Oaks. CA.

Bowen, D.E., \& Lawler, E.E., (1992), "The empowerment of service workers: What, why, how, and when". Sloan Management Review, 33 (.3), 31-9.

Burns, J., (1978), Leadership. Harper \& Row New York. NY.

Bycio, P., Hacket, R.D. \& Allen, J.S., (1995), "Further assessment of Bass's (1985) conceptualization of transactional and transformational leadership". Journal of Applied Psychology. 80: 468-478.

Cresswell, J.W., (1998), Qualitative inquiry and research design: choosing among five traditions. SAGE publications. London.

Dionne S.D., Yammarino F.J, Atwater L.E. \& Spangler W.D., (2003), "Transformational leadership and team performance". Journal of Organizational Change Management, 17 (2): 177-193.

Foster, D.P., Stine, B., \& Waterman, R., (1998), Business analysis using regression: a casebook. SpringerVerlag.

Hair, J.F., Anderson, R.E., Tatham, R.L., \& Black, W.C., (1998), Multivariate data analysis. Prentice Hall International Inc. New Jersey.
Hartog, D.N.D., Muijen J.J. \& Koopman V., (1997), "Transactional vs. transformational leadership: an analysis of the MLQ". Journal of Occupational and Organizational Psychology, 70: 19-34.

Honold, L., (1997), "A review of the literature on employee empowerment". Empowerment in Organizations, 5 (4): 202-212.

Howell, J.M., \& Avolio, B.J., (1993). "Transformational leadership, transactional leadership, locus of control and support for innovation: Key predictors of consolidatedbusiness unit performance". Journal of Service Marketing, 16, 487-502.

Humphreys, J. H., (2002), "Transformational leader behaviour, proximity and successful service marketing". Journal of Service Marketing, 16 (6): 487-502.

Jabnoun, N., \& AL Rasasi, A.J., (2005), "Transformational leadership and service quality in UAE hospitals". Managing Service Quality, 15 (1): 70-81.

Jaccard, J., Turrisi, R. \& Wan, C.K., (1990), Interaction effects in multiple regression, 72. SAGE Publications Inc. Newsbury Park California.

Keller, R.T., (1995), "Transformational leaders make a difference". Research Technology Management, 38 (3): 41-44.

Klidas, A., van den Berg, P.T. \& Wilderom, C.P.M., (2007), "Managing employee empowerment in luxury hotels in Europe". International Journal of Service Industry Management, 18 (1): 70-88. 
Lashley, C., (1999), “Employee empowerment in services: a framework for analysis". Personnel Review, 28 (3): 169-191.

Leedy, P.D. \& Ormrod, J.E., (2005), Practical research: planning and design. Pearson Education Ltd.

Locke, E. A. \& Latham, G. P., (1990), A theory of goal setting and task performance. Englewood Cliffs. Prentice Hall. NJ.

Menon, S.T., (2001), "Employee empowerment: an integrative psychological approach". Applied Psychology: An International Review, 50 (1): 153-80.

Nunally, J.C., \& Bernstein, I. H., (1994), Psychometric theory. New York: McGraw-Hill.

Parasuraman, A., Zeithmal, V.A. \& Berry, L.L., (1985), “A conceptual model of service quality and its implications for future research". Journal of Marketing, 49: 41-50.

Parasuraman, A., Zeithmal, V.A. \& Berry L.L., (1988), "SERVQUAL: a multiple-item scale for measuring consumer perceptions of service quality". Journal of Retailing, 64: $12-40$.

Pounder, J. S., (2002), "Employing transformational leadership to enhance the quality of management development instruction". Journal of Management Development, 22 (1): 6-13.

Sekaran, U., (2000), Research methods for business: a skill building approach. John Wiley \& Sins Inc. NY.

Spreng, R.A., MacKenzie S.B. \& Olshavasky R.W., (1996), "A reexamination of the determinants of consumer satisfaction". Journal of Marketing, 60: 15-32.

Spreitzer, G., (1995), "Psychological empowerment in the workplace: dimensions, measurement and validation". Academy of Management Journal, 38 (5): 1442-65.

Sternberg, L.E., (1992), “Empowerment: trust vs control". Cornell Hotel and Restaurant Administration Quarterly, 33 (1), 69-72.

Samsudin, S., (2008), Selected transformational leadership characteristics and service quality: A mediating role of empowerment. Unpublished Final Year Project Report. Universiti Malaysia Sarawak, Malaysia.

Vaan Maanen, J., (1983), Qualitative methodology. Sage Publications. Baverly Hills CA.

Waldman, D.A., (1993), A theoretical consideration for leadership and total quality management. Leadership Quarterly, 4 (1), 65-79.

Wong, C., Hui, C. \& Law, K.S., (1995), "Causal relationships between attitudinal antecedents to turnover". Academy of Management Journal, 342-346.

Wright, I.L., (1996), Qualitative international management research. In Punnett, B.J \& Shenker, O. Handbook for international management research. BlackWell Publishers Inc. UK.

Yammarino, F.J. \& Dubinsky, A.J., (1994), Transformational leadership theory: using levels of analysis to determine boundary conditions. Personnel Psychology, 47, 787811. 